\title{
PATTERNS OF SEEDLING RECRUITMENT IN EXPERIMENTAL GAPS ON MOSAIC VEGETATION OF ABANDONED MEADOWS
}

\author{
LIDIA BORKOWSKA \\ University of Podlasie, Departament of Botany, Institute of Biology \\ B. Prusa 12, 08-110 Siedlce, Poland \\ e-mail: lidiabor@ap.siedlce.pl
}

(Received: February 23, 2004. Accepted: May 13, 2004)

\begin{abstract}
The paper presents results of a study on the response of species growing in experimental gaps in the patches dominated by Carex acutiformis, C. cespitosa and Salix cinerea. The study was performed in a meadow area subjected to the process of succession in the Reski Range in the Białowieski National Park. Four patterns of seedlings recruitment in the experimental gaps were distinguished: pattern I - great number of seedlings with high richness of species, pattern II - great number of seedlings with low richness of species, pattern III - low number of seedlings with great richness of species and pattern IV - low number of seedlings with low richness of species.
\end{abstract}

KEY WORDS: seedlings appearance, seedlings recruitment, experimental gaps.

\section{INTRODUCTION}

It has been many times suggested that dense vegetation cover restricts the appearance and survivability of seedlings and thus affects the species turnover (Platt 1975; Grubb 1977; Harper 1977; Gross 1984; Peart 1989).

According to some hypotheses on the role of gaps, the free sites become regeneration niches and the appearance of gaps stimulates the species diversity (sensu Grubb 1977). As verification of these hypotheses in the gaps appearing as a result of natural disturbances is not always possible, experimental studies are often conducted

This study was undertaken to verify the hypothesis of the inhibiting role of the vegetation cover on development of seedlings in favourable for this study conditions of the mosaic structure of vegetation in abandoned meadows. Another aim of the study was to determine different patterns of seedling recruitment in the experimental gaps.

In particular the following hypotheses have been verified.

1. Experimental gaps stimulate the activity of seeds in the soil bank and therefore, many more seedlings appear in the gaps than in the dense vegetation cover.

2. Because of the neighbourhood of a forest, seedlings of forest species appear in the gaps.

3. The following four variants of the species composition are expected to appear:

a) meadow species present before the gap appearance, b) swamp species because of a neighbourhood of a river,

c) macroforb and brushwood species because of advanced succession,

d) species associated with disturbances (if the gaps are treated as the effect of disturbances).

\section{THE OBJECT OF STUDY}

The study was performed in the years 1995-1998 in the abandoned meadow in the Reski Range (15 ha) in the Białowieski National Park. The Range lies in the north-western part of the Białowieska clearing. Starting from 1972 it has been an object of study of the Białowieska Geobotanical Station.

The Narewka river valley at the section flowing through the Range was deforested about 200 years ago (Faliński 1966). Till the 50s of the last century the meadows had been regularly mown. Between the early 60s till 1978 the meadows were gradually abandoned. For over 30 years in this area spontaneous secondary succession has been observed. The meadows were abandoned at different times, so different stages of succession represented by different types of plant communities can be observed (Falińska 1991a, 2003).

In the early stages of succession some of the species originally present on the meadows dominated some fragments of the Range, e.g. there were fragments dominated by $\mathrm{Ca}$ - 
rex acutiformis, $C$. cespitosa and $C$. appropinquata or by macroforbs with prevalence of such species as Filipendula ulmaria, Lysimachia vulgaris and Lythrum salicaria.

\section{METHODS}

To study the effect of disturbances on the vegetation structure and response of species, in the spring of 1995 three study plots of $30 \mathrm{~m}^{2}$ have been selected for experimental study. The study plots were delimited in the patches dominated by different species:

- the plot in the patch with Carex acutiformis (A),

- the plot in the patch with Salix cinerea (B),

- the plot in the patch with Carex cespitosa (C).

Henceforth they will be referred to as plots A, B and C.

In each plot three transects of 10 in length and $1 \mathrm{~m}$ in width have been delimited, so altogether 10 study plots in each bigger plot. In each patch studied, dominated with a different species, some plots have been subjected to two types of disturbances (Fig. 1):

a) strong disturbance (I) - vegetation cover and a surface layer of soil (15-20 cm deep) have been removed - this disturbance corresponded to the effect of wild boar rooting, b) weak disturbance (II) - the plants have been cut down - this disturbance corresponded to mowing or browsing by animals.

In each patch there have been a few control plots (0) subjected to no disturbance.

The appearance of seedlings in the experimental and control plots was carried out from August 1995 to October 1996. Each time before the observation the ramets of sedges appearing in the study plots were counted and cut out. In the results analysis the highest number of seedlings appearing in a given year was taken into account. In each plot the number of seedlings (plants with a cotyledon and the first leaves) was recorded. The seedlings were identified with the help of the Csapodý key (1968).

\section{RESULTS}

\section{Patterns of seedlings recruitment in experimental gaps}

On the basis of the number of seedlings and the number of species represented in the pool of the seedlings in the first (1995) and the second (1996) year after disturbances, the following four patterns of seedlings recruitment were distinguished (Fig. 2).

a) The study area

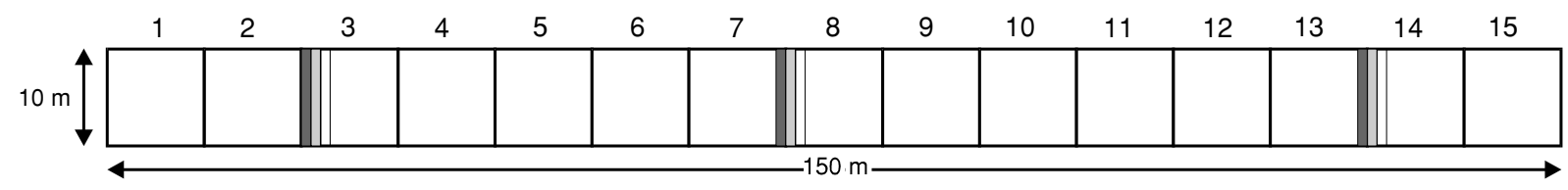

A

b) The experimental plots

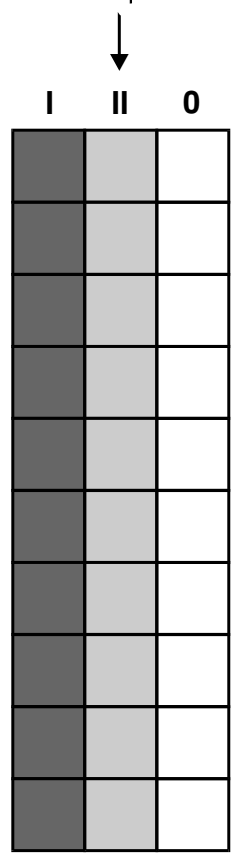

B

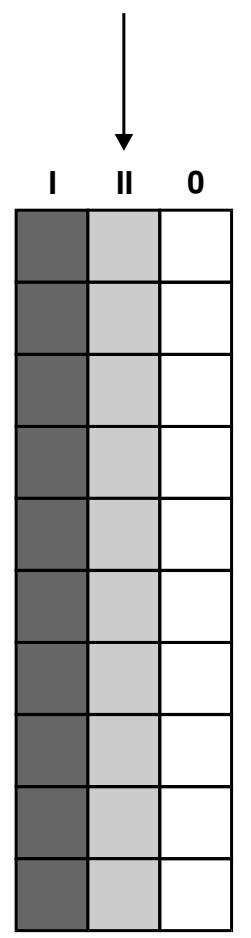

C

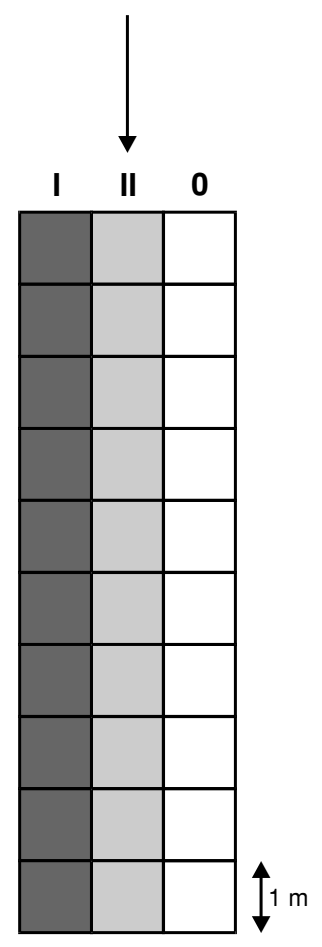

A - patch with Carex acutiformis

B - patch with Salix cinerea

C - patch with Carex cespitosa

Fig. 1. a) A scheme of the study area $\left(1500 \mathrm{~m}^{2}\right)$ divided into 15 squares of $10 \mathrm{~m}$ side, with 3 patches (A, B, C) delimited for the experimental study; b) a scheme of experimental plots $\left(30 \mathrm{~m}^{2}\right)$ in different patches. 


\begin{tabular}{|c|c|c|c|c|c|c|}
\hline \multirow{2}{*}{$\begin{array}{l}\text { Number of seedling } \\
\text { Number of species }\end{array}$} & \multirow{2}{*}{ Patterns } & \multicolumn{2}{|c|}{ Patches/disturbances } & \multicolumn{2}{|c|}{ Dominant species } & \multirow{2}{*}{ The other species } \\
\hline & & 1995 & 1996 & 1995 & 1996 & \\
\hline $\begin{array}{l}\text { seedlings: 1303-10493 } \\
\text { species: 12-21 }\end{array}$ & $\begin{array}{c}\text { I } \\
\begin{array}{c}\text { great number } \\
\text { of seedling }\end{array} \\
\text { high richness } \\
\text { of species }\end{array}$ & & & $\begin{array}{l}\text { Lythrum salicaria } \\
\text { Juncus } \mathrm{sp} \text {. }\end{array}$ & $\begin{array}{l}\text { Lythrum salicaria } \\
\text { Salix } \mathrm{sp} .\end{array}$ & $\begin{array}{l}\text { Angelica sylvestris } \\
\text { Caltha palustris } \\
\text { Cardamine } \mathrm{sp} . \\
\text { Cerastium holosteoides } \\
\text { Cirsium palustre } \\
\text { Cirsium rivulare } \\
\text { Cirsium } \mathrm{sp} .\end{array}$ \\
\hline $\begin{array}{l}\text { seedlings: } 1123-1409 \\
\text { species: 6-9 }\end{array}$ & $\begin{array}{c}\text { II } \\
\begin{array}{c}\text { great number } \\
\text { of seedling }\end{array} \\
\text { low richness } \\
\text { of species }\end{array}$ & & & & Lythrum salicaria & $\begin{array}{l}\text { Crepis paludosa } \\
\text { Galeopsis sp. } \\
\text { Geum rivale } \\
\text { Lathyrus pratensis } \\
\text { Lotus corniculatus } \\
\text { Lychnis flos-cuculi } \\
\text { Lycopus europaeus }\end{array}$ \\
\hline $\begin{array}{l}\text { seedlings: } 283-941 \\
\text { species: 13-18 }\end{array}$ & $\begin{array}{c}\text { III } \\
\begin{array}{c}\text { low number } \\
\text { of seedling }\end{array} \\
\text { great richness } \\
\text { of species }\end{array}$ & & & $\begin{array}{l}\text { Lythrum salicaria } \\
\text { Juncus } \mathrm{sp} . \\
\text { Poaceae }\end{array}$ & Galium sp. & $\begin{array}{l}\text { Mentha arvensis } \\
\text { Myosotis scorpioides } \\
\text { Polygonum bistorta } \\
\text { Polygonum hydropiper } \\
\text { Ranunculus acris } \\
\text { Ranunculus auricomus } \\
\text { Ranunculus flammula }\end{array}$ \\
\hline $\begin{array}{l}\text { seedlings: 53-788 } \\
\text { species: 2-9 }\end{array}$ & $\begin{array}{c}\text { IV } \\
\begin{array}{l}\text { low number } \\
\text { of seedling }\end{array} \\
\text { low richness } \\
\text { of species }\end{array}$ & & & $\begin{array}{l}\text { Lythrum salicaria } \\
\text { Epilobium } \mathrm{sp} \text {. } \\
\text { Filipendula ulmaria }\end{array}$ & $\begin{array}{l}\text { Lythrum salicaria } \\
\text { Juncus sp. } \\
\text { Poaceae } \\
\text { Salix sp. }\end{array}$ & $\begin{array}{l}\text { Ranunculus repens } \\
\text { Rumex acetosa } \\
\text { Scutellaria galericulata } \\
\text { siewka } \mathrm{x} \\
\text { Urtica dioica } \\
\text { Veronica } \text { sp. } \\
\text { Viola } \text { sp. }\end{array}$ \\
\hline
\end{tabular}

- patch with Carex acutiformis (A); $\triangle$-patch with Salix cinerea $(\mathrm{B}) ; \bigcirc$ - patch with Carex cespitosa $(\mathrm{C})$

$\square$ - strong disturbance; $\square$-weak disturbance; $\square$ - control plots

Fig. 2. Patterns of the seedling recruitment in the experimental gaps simulating the effects of different disturbances.

\section{Pattern I - great number of seedlings with high richness of species}

This pattern was noted in the two years of observation in all patches after the weak disturbance (cutting down of plants) and in the patch dominated by Carex acutiformis (A) after the strong disturbance (Fig. 2). The greatest number of seedlings (above 10 thousands) were found after the strong disturbance in the patch of Carex acutiformis (1995) and after the weak disturbance in the patch of Salix cinerea (1996).

The number of species in the pool of the seedlings varied from 12 to 21 . The seedlings in patch $\mathrm{C}$ represented the greatest number of species both after the strong and the weak disturbance, reaching from 17 to 21 . The maximum density of seedlings per $1 \mathrm{~m}^{2}$ varied from 298 to $1477 / \mathrm{m}^{2}$, while the minimum varied from 28 to 1029 seedlings $/ \mathrm{m}^{2}$ (Table 1, Fig. 3).

The taxa most numerously represented were Salix sp., Lythrum salicaria and Juncus sp. The highest number of Salix seedlings (10135) appeared in the gaps formed by cutting down plants in patch B (Salix cinerea). Above 5 thousand seedlings were noted in patch A (Carex acutiformis) after the strong disturbance and in patch $\mathrm{C}$ (Carex cespitosa) after the weak disturbance. The greatest number of seedlings of Juncus sp. (4650) was noted in the gaps in patch A (Carex acutiformis) after the strong disturbance (Fig. 2).

\section{Pattern II - great number of seedlings with low richness of species}

This pattern of seedlings recruitment was observed only in the second year (1996) after the strong disturbance in patches $\mathrm{A}$ and $\mathrm{C}$, dominated by sedges (Fig. 2). The number of seedlings varied from 1123 in patch $\mathrm{C}$ to 1409 in patch A.

The number species represented in the pool of the seedlings was low from 6 to 9 . The maximum density of seedlings per $1 \mathrm{~m}^{2}$ was similar in both patches and varied from 245 to 268 seedlings $/ \mathrm{m}^{2}$, while the minimum varied from 64 to 85 seedlings $/ \mathrm{m}^{2}$ (Table 1, Fig. 3). After either type of disturbance, the most abundant was the appearance of Lythrum salicaria seedlings.

\section{Pattern III - low number of seedlings with great richness of species}

In the first year of the study (1995) this type of pattern was observed in patch B after the two types of disturbances, in patch $\mathrm{A}$ after the weak disturbance and in patch $\mathrm{C}$ after the strong disturbance (Fig. 2). In the second year this pattern was observed only in patch $\mathrm{C}$ after the weak disturbance.

The number of seedlings was small and varied from 283 to 941 , the number of species represented in the pool of the seedlings was great and varied from 13 to 18 (Fig. 2). The maximum density of seedlings varied from 39 to 212 seedlings $/ 1 \mathrm{~m}^{2}$, while the minimum one - from 5 to 35 seedlings $/ 1 \mathrm{~m}^{2}$ (Table 1, Fig. 3). 
TABLE 1. The number of seedlings in the experimental and control plots in the years 1995-1996.

Number of seedlings in control plots $(0)$

\begin{tabular}{|c|c|c|c|c|c|c|c|}
\hline \multirow{2}{*}{ Patch } & \multirow{2}{*}{ Year } & \multirow{2}{*}{$\begin{array}{l}\text { Number of plots } \\
\text { with seedlings }\end{array}$} & \multicolumn{4}{|c|}{ Number of seedlings } & \multirow{2}{*}{$\begin{array}{l}\text { Number } \\
\text { of species }\end{array}$} \\
\hline & & & Total & $\bar{x} \pm \mathrm{SE}$ & $\max$ & $\min$ & \\
\hline Carex acutiformis & 1995 & 9 & 61 & $6.77 \pm 2.5$ & 21 & 1 & 5 \\
\hline A & 1996 & 3 & 60 & $20.00 \pm 13.7$ & 55 & 2 & 2 \\
\hline Salix cinerea & 1995 & 9 & 53 & $5.88 \pm 1.2$ & 11 & 3 & 7 \\
\hline $\mathrm{B}$ & 1996 & 9 & 788 & $87.55 \pm 33.9$ & 194 & 9 & 6 \\
\hline Carex cespitosa & 1995 & 9 & 196 & $21.77 \pm 3.9$ & 68 & 7 & 8 \\
\hline $\mathrm{C}$ & 1996 & 10 & 583 & $58.30 \pm 11.1$ & 113 & 2 & 9 \\
\hline
\end{tabular}

Number of seedlings in the gaps formed as a result of stronger disturbance (I)

\begin{tabular}{|c|c|c|c|c|c|c|c|}
\hline \multirow{2}{*}{ Patch } & \multirow{2}{*}{ Year } & \multirow{2}{*}{$\begin{array}{l}\text { Number of plots } \\
\text { with seedlings }\end{array}$} & \multicolumn{4}{|c|}{ Number of seedlings } & \multirow{2}{*}{$\begin{array}{l}\text { Number } \\
\text { of species }\end{array}$} \\
\hline & & & Total & $\bar{x} \pm \mathrm{SE}$ & $\max$ & $\min$ & \\
\hline Carex acutiformis & 1995 & 10 & $10417 * *$ & $1041.70 \pm 182.7 * *$ & 1058 & 1029 & $14 *$ \\
\hline A & 1996 & 10 & $1409 *$ & $140.90 \pm 54.5^{*}$ & 268 & 85 & 6 \\
\hline Salix cinerea & 1995 & 10 & 283 & $28.30 \pm 3.0$ & 39 & 17 & $13 *$ \\
\hline $\mathrm{B}$ & 1996 & 9 & 482 & $53.55 \pm 25.8$ & 98 & 6 & 4 \\
\hline Carex cespitosa & 1995 & 10 & 941 & $94.10 \pm 11.7$ & 212 & 22 & $17 * *$ \\
\hline $\mathrm{C}$ & 1996 & 10 & $1123 *$ & $112.30 \pm 34.1^{*}$ & 245 & 64 & 9 \\
\hline
\end{tabular}

Number of seedlings in the gaps formed as a result of weaker disturbance (II)

\begin{tabular}{|c|c|c|c|c|c|c|c|}
\hline \multirow{2}{*}{ Patch } & \multirow{2}{*}{ Year } & \multirow{2}{*}{$\begin{array}{l}\text { Number of plots } \\
\text { with seedlings }\end{array}$} & \multicolumn{4}{|c|}{ Number of seedlings } & \multirow{2}{*}{$\begin{array}{l}\text { Number } \\
\text { of species }\end{array}$} \\
\hline & & & Total & $\bar{x} \pm \mathrm{SE}$ & $\max$ & $\min$ & \\
\hline Carex acutiformis & 1995 & 10 & 668 & $66.80 \pm 4.4$ & 132 & 21 & $13 *$ \\
\hline A & 1996 & 10 & $1303^{*}$ & $130.30 \pm 18.3 *$ & 298 & 28 & $13 *$ \\
\hline Salix cinerea & 1995 & 10 & 758 & $75.80 \pm 6.9$ & 142 & 5 & $13^{*}$ \\
\hline B & 1996 & 10 & $10493 * *$ & $1049.30 \pm 291.6 * *$ & 1477 & 426 & $12 *$ \\
\hline Carex cespitosa & 1995 & 10 & $5994 * *$ & $599.40 \pm 117.0 * *$ & 659 & 545 & $21 * *$ \\
\hline $\mathrm{C}$ & 1996 & 10 & 737 & $73.70 \pm 5.3$ & 135 & 35 & $18 * *$ \\
\hline
\end{tabular}

differences statistically significant: $* \mathrm{P} \leq 0.05$, $* * \mathrm{P} \leq 0.01$

The most abundantly represented taxa were Lythrum salicaria, Juncus sp., Galium sp. and grass species. The greatest number of Lythrum salicaria seedlings appeared in patch C (Carex cespitosa) (412) after the strong disturbance and in patch B (Salix cinerea) (241) after the weak disturbance. The seedlings of Juncus sp. were most abundant after the strong disturbance in patch $\mathrm{C}$ (Carex cespitosa) (291). The greatest number of the seedlings of Galium sp. (188) was noted in patch A (Carex acutiformis) after the weak disturbance and the greatest number of grass species (159) appeared in patch B (Salix cinerea) (Fig. 2).

\section{Pattern IV - low number of seedlings with low richness of species}

This pattern was observed in control plots in all patches in the two years of study and in patch B in the second year of study after the strong disturbance (Fig. 2).

The number of seedlings varied from 53 to 788, and the number of species in the pool of the seedlings was from 2 to 9 . The maximum density of seedlings varied from 11 to 194 seedlings $/ 1 \mathrm{~m}^{2}$, while the minimum varied from 1 to 15 seedlings $/ 1 \mathrm{~m}^{2}$ (Table 1 ; Fig. 3 ).

The most abundantly represented were the 6 taxa Lythrum salicaria, Epilobium sp., Salix sp., Filipendula ulma- ria, Juncus sp. and grass species. The seedlings of Salix were most abundant (754) in the control plot in patch B (Salix cinerea) while the grass seedlings were most abundant (470) in patch B after the strong disturbance.

\section{DISCUSSION}

\section{Diversity of the patterns of seedlings recruitment after disturbances}

On the basis of the response of the seed bank to changes in the structure of communities Grubb (1977) distinguishes three types of relationships between the appearance of seedlings of different species and the type of disturbances in the vegetation structure: (1) the appearance of seedlings is stimulated by disturbances, e.g. treading, animal pressure, etc., (2) seedlings appear in a few years after the disturbance, (3) seedlings of the species tolerating shading by trees and shrubs appear, 4) the appearance of seedlings depends on continuous disturbances (e.g. grazing).

As follows from the analysis of the results of our observations, to the first group distinguished by Grubb (1977) belong the seedlings of the majority of species that appea- 
patch with Carex acutiformis $(\mathbf{A})$

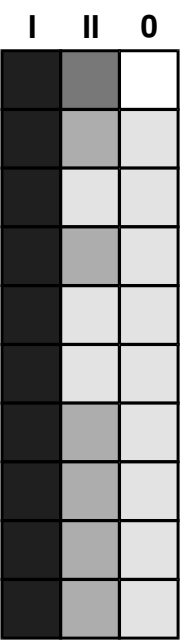

1995

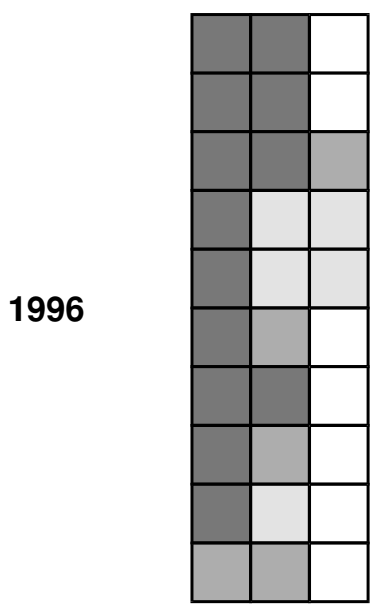

I - strong disturbance patch with Salix cinerea $(\mathbf{B})$
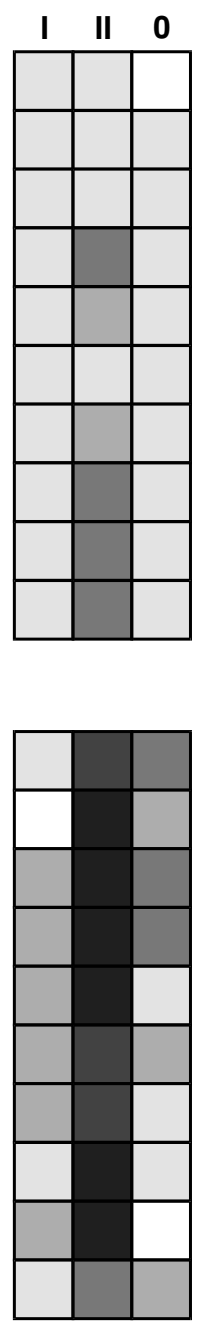

II - weak disturbance patch with Carex cespitosa $(\mathbf{C})$
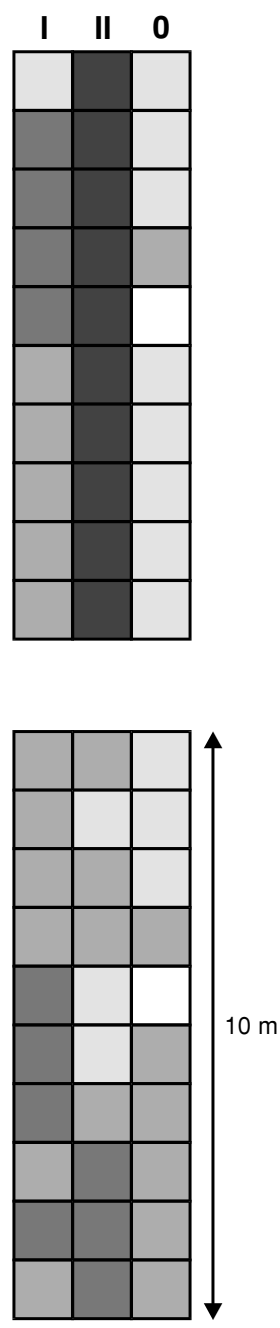

$\mathbf{0}$ - control plots

$1-50 / \mathrm{m}^{2} \quad \square \quad \square-100 / \mathrm{m}^{2}$

$101-500 / \mathrm{m}^{2}$

$501-1000 / \mathrm{m}^{2}$

above 1001 seedlings $/ \mathrm{m}^{2}$

Fig. 3. The density of seedlings in particular patches in the study plots and control plots in the years 1995-1996.

red in the gaps after the disturbances (Juncus sp., Lythrum salicaria, Epilobium sp.). The second group - the seedlings appearing a few years after disturbance - include the seedlings of Salix that appeared in the second year (1996) after the weak disturbance and in the third year (1997) after the strong disturbance (Borkowska 2001). These seedlings most probably developed from the seeds from airborne dispersal. The third group of shade-tolerating species includes seedlings of different species of grasses appearing in the gaps formed after the strong disturbance in patch B. The fourth group could not have been distinguished as the disturbances were inflicted only once. As follows from literature data, the occurrence of large patches of annual plants in forest communities e.g. Impatiens noli-tangere, is a result of repeatable disturbances forming gaps colonised by short-lived species (Falińska 1990).

It has been documented that the dense vegetation cover is a factor restricting the appearance and survivability of species in succession (Platt 1975; Grubb 1977; Harper 1977; Gross 1984; Peart 1989a), and thus restricting the exchange of species. It has been also shown that formation of gaps is the only or the main condition for the appearance of new individuals in many communities, especially those of dense vegetation cover (Remmert 1991). According to Mc Clure and Lee (1993), the occurrence of gaps is a factor enhancing the richness of species and diversity of forest communities.

The cessation of mowing of the Cirsietum rivularis meadow in the Narewka River valley in Reski Range stimulated the appearance of species characterised by the ability to form large patches. The naturally and artificially formed gaps were colonised by individuals of different species, mainly forest ones (Falińska 1991b). As follows from the study by Kołos (1997), a return to mowing after many years of abandonment, leads to formation of gaps in the dense patches of sedges, in which plants of the species hitherto inhibited mainly by swamp species, appeared. The mown areas were colonised by meadow and forest species.

The results of our study confirm that cutting down plants (the weak disturbance in our study) caused a return of meadow species immediately after the disturbance. These returning meadow species had earlier occurred sporadically 
in the vegetation cover, e.g. Lychnis flos-cuculi, Cirsium palustre, Lathyrus pratensis. The seedlings of these species had greater chances of appearing after the removal of the vegetation cover than in undisturbed conditions. In two years after the disturbance the meadow species were ousted by the species that dominated in a given patch. A similar response was noted by Pettit et al. (1995) and Sala (1988) who observed the effect of grazing.

In the gaps formed by removal of plants and the upper layer of soil (strong disturbance) in the first year (1995) the number of species represented was high (13-17) and in the next year it significantly decreased (3-4). The high number of species in the pool of seedlings in 1995 indicates germination of the majority of seeds present in the soil, and in the next year the seedlings came from the soil seed bank (Lythrum salicaria in sedge patches and grasses in Salix patch) and from airborne dispersal (Salix sp.).

The appearance of seedlings in many plant communities is determined by formation of gaps. Many authors have indicated that the soil seed bank gets activated on disturbance of the vegetation structure (Fenner 1985; Grubb 1977; Grime 1979; Harper 1977), which is confirmed by the results of this study. Eriksson (1989) has given three patterns of seedling recruitment in population of clonal species: 1) the pattern of repeated recruitment (regular appearance of seedlings in the mature genets); 2) pattern of initial recruitment (the appearance of seedlings only in the early phase of colonisation); 3) pattern of seedling appearance facilitated by wind seed dispersal. Let's refer the patterns of seedlings recruitment proposed in this work to those proposed by Eriksson (1989). Pattern 1 of repeated recruitment of seedlings is observed in all experimental gaps in all patches. Pattern 3 according to Eriksson, that is the appearance of seedlings facilitated by wind seed dispersal can be found only for seedlings of Salix coming from the seeds brought with the wind. On the basis of the results presented in this paper it is impossible to distinguish the species whose seedlings appeared only in the early phase of colonisation (2nd pattern according to Eriksson).

The colonisation success of a given species depends on many factors, among others on the floristic combination, space to be colonised, the competition from other colonists, mode of reproduction, type of growth and length of life (Grubb 1977; Falińska 1991a; Namura-Ochalska 1993).

Depending on the biological properties of the species dominant in a given patch, the effect of disturbances is different. It is interesting to note that the formation of gaps has not resulted in the appearance of seedlings representing species other than already present in the vegetation cover during the study (Borkowska 1996, 1998). Results of this study have shown that disturbances in the vegetation cover has significantly increased the number of seedlings and the number of species in all patches, relative to the undisturbed areas.

The most abundantly represented in the gaps were the seedlings of the following species: Lythrum salicaria, Salix sp., Juncus sp. and Epilobium sp. rarely met in natural meadow vegetation. There is every reason to suppose that the germinating seeds of Lythrum salicaria, and Juncus sp. came from the soil seed bank (Borkowska 2001). Very high number and frequency of Lythrum salicaria seedlings in the Reski Range have been reported by Falińska, JankowskaBłaszczuk and Szydłowska (1994).

\section{Gaps as regeneration niches}

In many communities it has been observed that each site in biochora can be colonised by almost each species, depending on the seeds appearing at this site at a given time. The appearance of different species has been reported in gaps formed in dense meadow vegetation cover, suggesting that the formation of gaps determines the species diversity of meadow communities (Rabotnov 1985a, 1985b).

In this study we assumed that experimental gaps in the vegetation patches undergoing advanced secondary succession would trigger a mechanism of species exchange. We expected that cutting down of plants (weak disturbance) or removal of the vegetation cover and soil layer (strong disturbance) would uncover safe sites for germination (Harper 1977), opening a chance of appearance of different species, including meadow species present there 20 years ago.

However, the analysis of our results proved that the gaps formed by removal of vegetation cover and soil layer in patch B (Salix cinerea) do not play the role of regeneration niches. This conclusion is supported by a) the number of seedlings and the number of species in the pool of the seedlings was lower than on control fields, b) the species composition after the 4 years of the experiment was poorer than at the initial state, c) the degree of the gap colonisation by plants was the lowest in patch B (Salix cinerea) relative to patches $\mathrm{A}$ and $\mathrm{C}, \mathrm{d}$ ) the spatial structure of the vegetation was not reproduced. Thus, it can be assumed that the gap was not a safe germination site (sensu Harper 1977) for seeds. The factors that might have contributed to restricting the germination in patch B were: 1) long-term flooding in the vegetation season, 2) shading by willows, 3) a small number of seeds in the soil bank despite a great richness of species (laboratory tests) (Borkowska 2001).

As indicated by many data, the species in communities take part in a lottery to win the life space as gaps formation is unpredictable and are colonised in a different way. Moreover, the gaps playing the role of regeneration niches, as suggested by Grubb (1977), not necessarily favour the species richness as often they enhance the dominance of some species e.g. Rubus sp. or Urtica dioica in disturbed forest communities.

According to the results of this study, it is possible to regenerate the species and spatial vegetation structure after disturbances, but the gap formation as a result of disturbances not always leads to enrichment of the species composition as indicated by (Sala 1988; Kołos 1997), but on the contrary it may lead to a dominance of a single species. Thus, our results do not confirm the hypothesis of Grubb (1977) saying that moderate disturbances enhance floristic richness. His hypothesis should rather be applied to the number of species in the pool of seedlings of which only a small group plays a determining role in colonisation of free space Thus gaps are safe sites for germination for seeds (sensu Harper 1977) so stimulate the appearance of seedlings, which not always leads to regeneration of disturbed areas, and in particular to the return of the species earlier present at a given site.

According to the dominant opinion the soil surface is a sieve determining the percent of germinating seeds (Harper and Sagar 1953; Harper and White 1970). The authors of this concept suggest that the safe sites for germination are, among others, all kinds of hollows and depressions in 
the ground surface. The effect of such elements of the ground sculpture has been observed in one-year species such as Salicornia patula (Wilkoń-Michalska 1976), Cerastium semidecandrum (Symonides 1979), Verbascum thapsus (Gross 1980), and in such perennials as Ranunculus bulbosus and $R$. repens (Harper and Sagar 1953), Senecio rivularis and S. umbrosus (Czarnecka 1995). For Puccinellia distans the safe sites for germination seem to be moist depressions in the ground, as in them the appearance of seedlings is abundant and they attain subsequent developmental stages (Lembicz 1995, 1998).

Restriction of germination and seedling appearance by accumulated necromass of the same species (supposedly toxic for the site) has been noted for Cirsium palustre (Ballegaard and Warncke 1985), Salicornia patula (WilkońMichalska 1976) and Plantago major (Miao et al. 1991). The smallest number of seedlings appeared in an undisturbed site although there were parts of the space totally devoid of plants. These free fragments can be treated as regeneration niches (sensu Grubb 1977), which did not contain enough safe sites for germination (sensu Harper 1977).

\section{Response of species to formation of experimental gaps}

As follows from the results of our study, disturbances lead a different effect depending on the species dominant in a given patch. Interestingly, the formation of gaps did not cause the appearance of seedlings of the species other than those currently occurring in the vegetation cover (Borkowska 1996, 1998, 2001). The results of the study have shown that the disturbance of the vegetation cover significantly increased the number of seedlings and the number of species relative to that in the undisturbed vegetation.

The strongest response to disturbances showed two species: Lythrum salicaria and Juncus sp., sporadically present in undisturbed meadow vegetation. The data indicate that the germinating seeds of Lythrum salicaria and Juncus sp. came from the soil seed bank, which has been confirmed by laboratory tests (Borkowska 2001). According to some authors (Cook 1980; Milberg 1990; Roberts 1981; Thompson 1987; Thompson et al. 1997) the appearance of the seedlings of Juncus effusus, Lythrum salicaria, Rubus sp. and Urtica dioica is related to the occurrence of free sites for germination as a result of disturbances and to a long-time storage of the seeds of these taxa in the soil. The greatest number of Lythrum salicaria and Juncus sp. were noted in patches $\mathrm{A}$ and $\mathrm{C}$, while in patch B seedlings of these species were sporadically observed due to the shading.

It was observed that the disturbed experimental plots in all patches studied were colonised by the species sporadically occurring in the current vegetation cover. The gaps made increased a possibility of appearance of meadow species (e.g. Lychnis flos-cuculi, Myosotis scorpioides, Galium sp. etc.). The results confirmed that infliction of all kinds of disturbances stimulates the seeds from the soil seed bank (Kjellson 1991; Harper et al. 1965; Roberts and Boddrell 1983; Van Der Valk and Davis 1978). In two years after the experiment the majority of seedlings came from the seed bank (e.g. Lythrum salicaria, Juncus sp. and meadow species). In the following years the germination of seeds from airborne dispersal (e.g.. Salix sp.) increased (Borkowska 2001).

\section{CONCLUSIONS}

1. In all experimental gaps the number of species and richness of species in the pool of seedlings was greater than on the control plots.

2. The types of species represented in the pool of seedlings depend on the dominant species in a given patch and on the type of disturbance.

3. Directly after the cutting down of plants (weak disturbance) in the gaps thus formed the meadow species, sporadically present in the current vegetation, appeared. After two years they were ousted by the species dominant in a given patch.

4. In the experimental gaps the most abundantly represented were the seedlings of Juncus sp. and Lythrum salicaria coming from the seed bank and those of Salix sp., coming from airborne dispersal.

5. In all experimental plots the gaps formed as a result of inflicted disturbance played a role of regeneration niches (sensu Grubb 1977) - the species richness increased after the study, the only exception were the gaps in patch B ( $\mathrm{Sa}$ lix cinerea).

\section{ACKNOWLEDGEMENTS}

My sincere thanks go to Prof. dr hab. Krystyna Falińska for kind supervision and encouragement for the study. I am much grateful to Prof. dr hab. Janusz B. Faliński for allowing me to stay at the Białowieska Geobotanical Station of the Warsaw University. Thanks are also due to Dr Marek T. Ciosek for kind agreement for my work in Białowieża and to Krzysztof Sulej for help in the paper graphics.

\section{LITERATURE CITED}

BALLEGAARD T.K., WARNCKE E. 1985. Observations on autotoxic effects on seed germination and seedling in Cirsium palustre from a spring area in Jutland, Denmark. Holarctic Ecol. 8: 63-65.

BORKOWSKA L. 1996. Pojaw siewek w mozaikowej roślinności porzuconych łąk (wstępny wynik eksperymentu). Phytocoenosis 8 (N.S.) Sem. Geobot. 4: 69-82 (in Polish).

BORKOWSKA L. 1998. Wpływ pokrywy roślinnej na wymianę gatunków w procesie sukcesji na łące (badania eksperymentalne), In: J. Miądlikowska (ed.), Botanika polska u progu XXI wieku. Materiały sympozjum i obrad sekcji 51 Zjazdu PTB Gdańsk 15-19.09 1998 (in Polish).

BORKOWSKA L. 2001. Zaburzenia wywołane eksperymentalnie w zbiorowisku niekoszonej łąki Cirsietum rivularis Ralski 1931 a funkcjonowanie niszy regeneracyjnej. Ph.D. Thesis, Akademia Podlaska, Siedlce (in Polish).

COOK R. 1980. The Biology of Seeds in the Soil. In: O.T. Solbrig (ed.), Demography and Evolution in Plant Populations, 107-128. Columbia Univ. Press. New York.

CSAPODÝ V. 1968. Keimlings-Bestimmungsbuch der Dikotyledonen. Akadémiai Kiadó. Budapest, 286 pp.

CZARNECKA B. 1995. Biologia i ekologia izolowanych populacji Senecio rivularis (Waldst. Et Kit.) DC. i Senecio umbrosus Waldst. Et Kit. UMCS, Rozprawy Wydz. BiNoZ, Rozprawy habilitacyjne 48. Lublin, 263 pp (in Polish)

DE HULLU E., GIMINGHAM C.H. 1984. Germination and establishment of seedlings in different phases of the Calluna lifecycle in a Scottish heathland. Vegetatio 58: 115-121. 
ERIKSSON O. 1989. Seedling dynamics and life histories in clonal plants. Oikos 55: 231-238.

FALIŃSKA K. 1990. Osobnik, populacja, fitocenoza. PWN, Warszawa, 310 pp (in Polish).

FALINSKA K. 1991a. Plant demography in vegetation succession. Kluwer Academic Publisher, Dordrecht-Boston-London, $210 \mathrm{pp}$.

FALIŃSKA K. 1991b. Sukcesja jako efekt procesów demograficznych roślin. Phytocoenosis 3 (N.S.) Sem. Geobot. 1: 43-67. (in Polish)

FALIŃSKA K. 1996. Ekologia roślin. Wyd. Naukowe PWN, Warszawa, 453 pp (in Polish).

FALIŃSKA K. 2003. Alternative pathways of succession: Species turnover patterns in meadows abandoned for 30 years. Phytocoenosis 15 (N.S.) Arch. Geobot. 9: 1-104.

FALIŃSKA K., JANKOWSKA-BŁASZCZUK M., SZYDŁOWSKA J. 1994. Bank nasion w glebie a dynamika roślinności. Wiad. Bot. 38 (1/2): 35-46 (in Polish).

FALIŃSKI J.B. 1966. Antropogeniczna roślinność Puszczy Białowieskiej jako wynik synantropizacji naturalnego kompleksu leśnego. Rozpr. Uniw. Warsz., 256 pp (in Polish).

FENNER M. 1985. Seed Ecology. Chapman and Hall, London-New York, $151 \mathrm{pp}$.

GOLDBERG D.E., WERNER P.A. 1983. The effect of size of opening in vegetation and litter cover on seedling establishment of goldenrods (Solidago sp.). Oecologia 60: 149-155.

GRIME J.P. 1979. Plant strategies and vegetation processes. J. Wiley and Sons, Chichester-New York-Brisbane-Toronto-Singapore, $222 \mathrm{pp}$.

GROSS K.L. 1980. Colonization of Verbascum thapsus (Mullein) in an old field in Michigan the effects of vegetation. Vegetatio 68: 919-928.

GROSS K.L. 1984. Effects of seed and growth form on seedling establishment of six monocarpic perennial plants. J. Ecol. 72: 369-387.

GRUBB P.J. 1977. The maintenance of species richness in plant communities: The importance of the regeneration niche. Biol. Rev. Cambridge Philos. Soc. 52: 107-145.

HARPER J.L. 1977. Population Biology of Plants. Academic Press, London-New York-San Francisco, 896 pp.

HARPER J.L., SAGAR G.R. 1953. Some aspects of the ecology of buttercups in permanent grassland. Proceedings of the British Weed Conference 1958: 256-265.

HARPER J.L., WHITE J. 1970. The dynamics of plant populations. Proc. Adv. Study Inst. Dynamics Numbers Popul. 41-63.

HARPER J.L, WILIAMS J.T., SAGAR G.R. 1965. The behaviour of seeds in the soil. 1. The heteregeneity of soil surfaces and its role in determining the establishment of plants. J. Ecol. 53: 273-286.

KJELLSON G. 1991. Seed banks in Danish deciduous forests: species composition, seed influx and distribution pattern in soil. Ecography 15: 86-100.

KOŁOS A. 1997. Dynamika strefy przejścia między zbiorowiskami leśnymi i nieleśnymi w dolinie rzeki Narewka. Ph.D. Thesis, Białowieża-Białystok, 79 pp (in Polish).

LEMBICZ M. 1995. Struktura demograficzno-genetyczna populacji Puccnellia distans (L.) Parl. i jej zmiany w toku kolonizacji siedlisk antropogenicznych. Ph.D. Thesis, Uniwersytet im. Adama Mickiewicza, Poznań (in Polish).

LEMBICZ M. 1998. Life history of Puccinellia distans (L.) Parl. (Poaceae) in the colonization of anthropogenic habitats. Phytocoenosis 10 (N.S.) Archivum Geobot. 7: 1-34.
MIAO S.L., BAZZAZ F.A., PRIMACK R.B. 1991. Persistence of maternal nutrient effects in Plantago major, the third generation. Ecology 72: 1634-1642.

MC CLURE J.W., LEE T.D. 1993. Small-scale disturbance in a northern hardwoods forests: effects on tree species abundance and distribution. Can. J. For. Res. 23: 1347-1360.

MC CONNAUGHAY K.D.M., BAZZAZ F.A. 1987. The relationship between gap size and performance of several colonizing annuals. Ecology 68: 411-416.

MC CONNAUGHAY K.D.M., BAZZAZ F.A. 1990. Interaction among colonizing annuals: Is there an effect of gap size? Ecology 71: 1941-1951.

MILBERG P. 1990. What is the maximum longevity of seeds? Sven. Bot. Tidskr. 84: 323-352.

Namura-Ochalska A. 1993. Expansion of Tussilago farfara L. in disturbed environments. Acta Soc. Bot. Pol. 62.1-2: 75-99.

NOBLE I.R. 1980. Interaction between tussock grass (Poa spp.) and Eucalyptus pauciflora seedlings near tree line in south eastern Australia. Oecologia (Berlin) 45: 350-353.

PEART R.D. 1989. Species interactions in a successional grassland. I. Seed rain and seedling recruitment. J. Ecol. 77: 236-251 .

PETTIT N.E., FROEND R.H., LADD P.G. 1995. Grazing in remnant woodland vegetation: changes in species composition and life form groups. J. Veg. Sci. 6: 121-130.

PLATT W.J. 1975. The colonization and formation of equilibrium plant species associations on bardger disturbance in a tall-grass prairie. Ecol. Monogr. 45: 285-305.

REMMERT H. (ed.). 1991. The Mosaic-Cycle Concept of Ecosystems. Springer-Verlag.

RABOTNOV T.A. 1985a. Dynamics of plant coenotic populations. In: J. White (ed.), The population structure of vegetation: 121-142. Dr W. Junk Publishers-Dordrecht-Boston, London.

RABOTNOV T.A. 1985b. Fitocenologia. Ekologia zbiorowisk roślinnych. PWN, Warszawa (in Polish).

ROBERTS H. 1981. Seed bank in soils. Advances in Applied Biology 6: 1-55.

ROBERTS H., BODDRELL J.E. 1983. Seed survival and periodicity of seedling emergence in the species of annual weed. Ann. App. Biol. 102: 523-532.

SALA O.E. 1988. The effect of herbivory on vegetation structure. In: M.J.A. Werger, P.J.M. Van der Aart, H.J. During, J.T.A. Verhoeven (eds), Plant form and vegetation structure, 317 -330. SPB Academic Publishing.

SYMONIDES E. 1979. The structure and population dynamics of psammophytes on inland dunes. III. Populations of compact psammophyte communities. Ekol. Pol. 27: 235-257.

THOMPSON K. 1987. Seeds and seed banks. New Phytol. 106, Suppl. 23-24.

THOMPSON K., BAKKER J.P., BEKKER M.R. 1997. The soil seed banks of North West Europe: methodology, density and longevity. Cambridge University Press, Cambridge.

VAN DER VALK A.G., DAVIS C.B. 1978. The role of seed bank in the vegetation dynamics of prairie glacial marshes. Ecology 59: 322-335.

WILKOŃ-MICHALSKA J. 1976. Struktura i dynamika populacji Salicornia patula Duval-Jouve. Rozpr. UMK Toruń (in Polish). 